\title{
Lake Breezes in Southern Ontario and Their Relation to Tornado Climatology
}

\author{
Patrick W. S. King, Michael J. Leduc, David M. L. Sills, Norman R. Donaldson, David R. Hudak, \\ Paul Joe, and Brian P. Murphy \\ Meteorological Service of Canada, Toronto, Ontario, Canada
}

(Manuscript received 26 March 2002, in final form 14 February 2003)

\begin{abstract}
Geostationary Operational Environmental Satellite (GOES) imagery is used to demonstrate the development of lake-breeze boundaries in southern Ontario under different synoptic conditions. The orientation of the gradient wind with respect to the shorelines is important in determining the location of such lines. When moderate winds $\left(5-10 \mathrm{~m} \mathrm{~s}^{-1}\right)$ are parallel to straight sections of coastlines, cloud lines can extend well inland. In the region between Lakes Huron and Erie lake-breeze lines merge frequently, sometimes resulting in long-lasting stationary storms and attendant heavy rain and flooding. The influence of the lakes is apparent in the tornado climatology for the region: tornadoes appear to be suppressed in regions visited by lake-modified air and enhanced in regions favored by lake-breeze convergence lines. The cloud patterns in the case of a cold front interacting with merging lake-breeze boundaries are shown to be similar to those on a major tornado outbreak day. Two of the cases discussed are used as conceptual models to explain many of the features in the patterns of tornado touchdown locations. In general, it appears that the lakes suppress tornadoes in southern Ontario, compared with neighboring states and in particular in areas where southwest winds are onshore, but enhance tornado likelihood locally in areas of frequent lake-breeze activity.
\end{abstract}

\section{Introduction}

The effects of the Great Lakes on winter weather in southern Ontario are well known (see Burrows 1991) but there has been less systematic study of summertime effects. Shenfeld and Thompson (1962) discussed two cases in which severe thunderstorms formed on lakebreeze fronts at the west end of Lake Ontario. Forecasters at the Regional Centre Toronto Office (RCTO) (Murphy 1991; Leduc et al. 1993) have pointed out the likely involvement of lake breezes in severe weather events. Clodman and Chisholm $(1994,1996)$ related maxima in lightning climatology and the occurrence of quasistationary rainstorms to lake breezes.

The lead author began studying lake breezes and their effects on summer severe weather in 1994 with the cooperation of forecasters at RCTO. King et al. (1996, hereafter KLM96) demonstrated a relationship between lake breezes and tornado climatology in southern Ontario. King (1997) suggested that a tornado maximum in the central part of the southwestern Ontario peninsula is due to the deep inland penetration and merger of convergence lines from Lake Erie and Lake Huron. King

Corresponding author address: Mr. Patrick King, Meteorological Service of Canada, 4905 Dufferin St., Toronto, ON M3H 5T4, Canada.

E-mail: patrick.king@ec.gc.ca
(1996) discussed a case in which merging lake-breeze convergence lines resulted in a long-lasting squall line with heavy rain, golfball-sized hail, and damaging winds. The results described in these papers and from the Southern Ontario Oxidant Study-Meteorological Measurements (SOMOS) project (Sills et al. 1994) led to the Effects of Lake Breezes on Weather (ELBOW) project in 1997 (King et al. 1999) to study the inland penetration and merger of lake breezes. Some preliminary modeling results of a quasi-stationary multicellular cluster that formed at the merger point of the Erie and Huron convergence lines during ELBOW have been reported previously (Sills and King 1998; Sills 1998).

The purpose of this study is to demonstrate the characteristics of lake breezes and their effects on summertime convection in southern Ontario, in particular on tornado climatology. Effects of irregular shorelines, interactions with the mean flow, and interactions with cold fronts will be illustrated using satellite imagery. We show several days with mean flow from the southwest since that surface wind direction is most often associated with summer severe weather. Since the development of lake-breeze convergence lines is closely related to wind direction, a few events with flows from other directions will be shown as well. This work is intended to set the stage for modeling studies and further field work to elucidate the physical processes described here. 


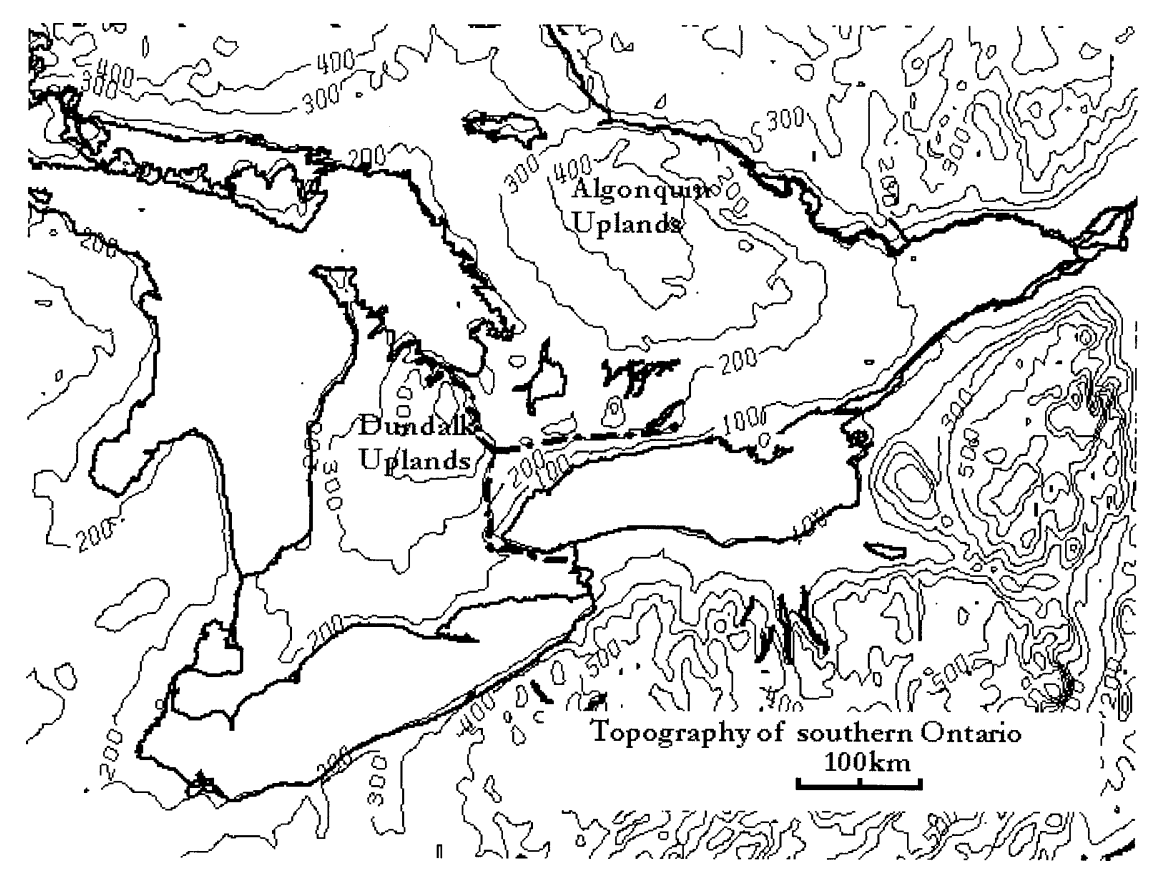

FIG. 1. Topographical map of southern ON. Height contours are in m MSL. The dash-dot lines are the Niagara Escarpment and Oak Ridges Moraine.

\section{Geography and physiography of southern Ontario}

Southern Ontario (Fig. 1) can be divided into two parts: southwestern Ontario, a peninsula bounded by Lake Erie, Lake Huron, and western Lake Ontario, and eastern Ontario, the region lying east of Georgian Bay and north of Lake Ontario. Names of places and features referred to in the text are shown in Fig. 2.

The principal physiographic feature in southwestern Ontario is the Niagara Escarpment, which runs parallel to the south coast of Lake Ontario, north along $80^{\circ} \mathrm{W}$ to Georgian Bay, and then to the northwest. Elevations rise gently about $200 \mathrm{~m}$ from the level of Lakes Huron and Erie to the Dundalk Uplands and then drop sharply east of the escarpment. The eastern and northern faces of the escarpment are steeply sloped in places; at the southern end of Georgian Bay there is a drop of $200 \mathrm{~m}$ over a distance of a few kilometers.

Southwest of London the main peninsula narrows to $80 \mathrm{~km}$ wide between Lakes Huron and Erie, with a further narrowing to $40 \mathrm{~km}$ in Essex County. North of Lake Erie east of London, the land is relatively flat and most of the relief occurs at the shoreline where there are $10-30-\mathrm{m}$ bluffs along much of its length. Several significant peninsulas break the Lake Erie coast, notably Long Point extending about $40 \mathrm{~km}$ into the lake, and Point Pelee and Pointe aux Pins farther to the west.

Although the area west of the escarpment is generally flat to gently rolling, there are areas of more significant relief owing to glacial features such as moraines and drumlin fields.

The northern coastline of Lake Ontario is more reg- ular than that of Lake Erie, but the topography is more complex. The Oak Ridges Moraine runs east from the escarpment roughly $30 \mathrm{~km}$ north of the lake. At the western end it is 200-300 m higher than the level of Lake Ontario so there can be significant upslope conditions with southerly winds. East of Georgian Bay the land rises about $200 \mathrm{~m}$ to the Algonquin Highlands, which is bordered on the east by an escarpment.

\section{Sea breezes and lake breezes}

\section{a. Interactions with the gradient wind and topography}

In this section we briefly review some results concerning lake breezes and sea breezes, concentrating on studies in the Great Lakes. For a more general discussion and a complete list of references, the reader is referred to Pielke (1984) or Simpson (1994).

Wexler (1946) noted that the gradient wind, topography and coastline irregularities, and atmospheric stability were all important factors in determining the characteristics of a sea-breeze circulation. In particular, he noted that in regions with pronounced topography, upslope and sea-breeze circulations developed independently but later combined into one system.

In a series of papers based on both observational and modeling studies, Estoque (Estoque 1962, 1981; Estoque and Gross 1981) established the basis of interactions between sea or lake breezes and the mean flow. His ideas have been extended by others including Pielke (1974), Savijarvi and Alestalo (1988), Arritt (1993), and Comer and McKendry (1993). 


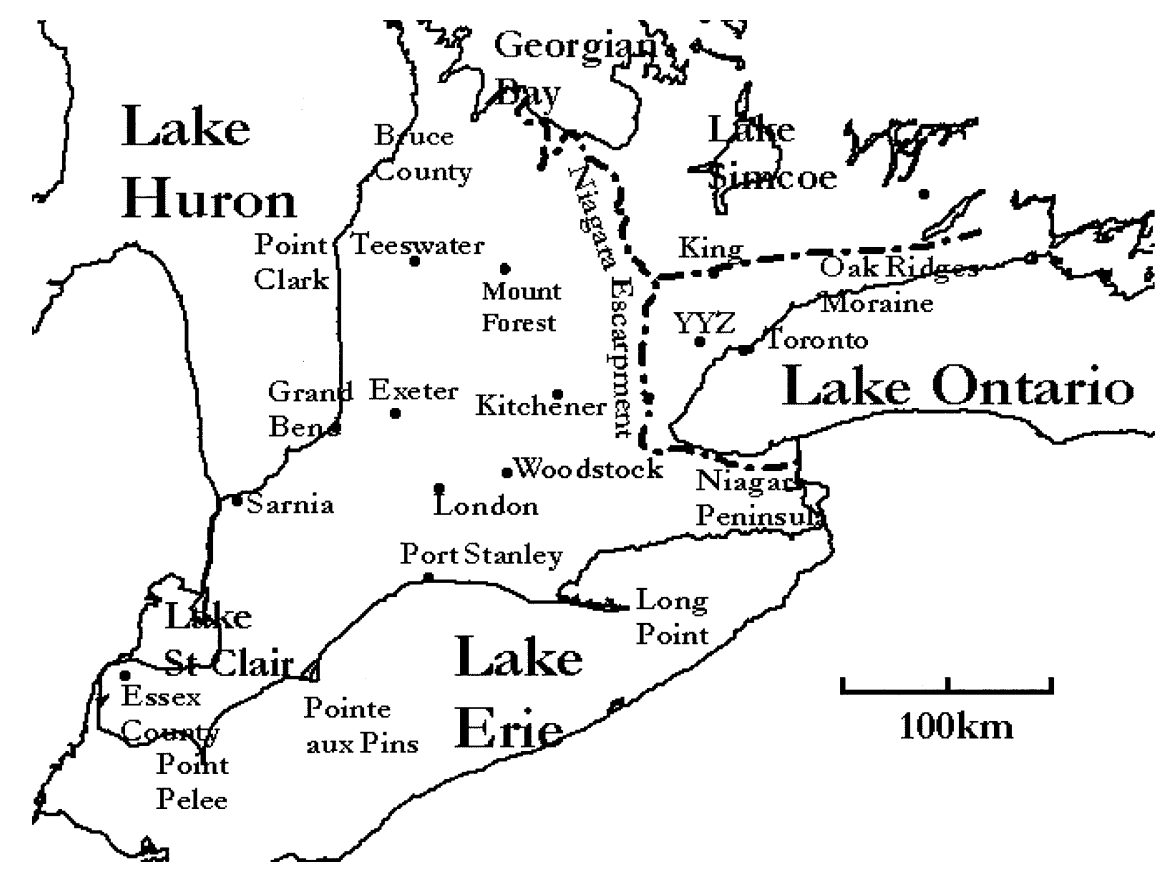

FIG. 2. Place names and geographical features in southwestern ON. The Niagara Escarpment and Oak Ridges Moraine are marked by the dash-dot line.

Using a 2D model, Estoque (1962) found that, under an offshore gradient wind, a sea-breeze front formed but moved inland only a few kilometers. When the wind was onshore, the sea-breeze circulation was much weaker but moved well inland. When winds were parallel to the coastline, inland penetration and strength depended on the direction of the pressure gradient with respect to the shoreline. When the lower pressure was over the water, frictional convergence resulted in an offshore component and the sea-breeze front developed near the coast. When lower pressure was over land, it was analogous to the onshore situation and the convergence line was weaker and farther inland.

Estoque (1981) and Estoque and Gross (1981) made observational and theoretical studies (using a 3D model) of the Lake Ontario lake breeze to study gradient wind and topographical effects. Lake breezes penetrated as much as $50 \mathrm{~km}$ inland by 1800 eastern standard time (EST). A double maximum formed in the vertical velocity field on the north side of the lake; one maximum due to the lake breeze and the other apparently induced by the Oak Ridges Moraine. As the lake breeze moved inland, the two maxima combined. They attributed discrepancies from theoretical expectations to the complicated configuration of the shorelines and to horizontal nonuniformities in orographic features.

Comer and McKendry (1993) extended these results using the Colorado State Model (CSU) model (Pielke 1974) to model Lake Ontario lake breezes with gradient flows from SW to $\mathrm{N}$. They used idealized versions of real cases with weak gradients $\left(1.7-3.7 \mathrm{~m} \mathrm{~s}^{-1}\right)$ to initialize the model. In all cases they found significant inland penetration north of Lake Ontario: penetrations ranging from about $30 \mathrm{~km}$ at the west end of the lake to 80 at the east end. Their model domain included Lake Simcoe and parts of Lake Erie and Georgian Bay. Although they do not mention it, their figures clearly show interactions between the Lake Ontario lake breeze and lake breezes from Lake Erie and Georgian Bay.

Lyons (1971) discussed the formation of a shallow anticyclone over Lake Michigan. He pointed out that short segments of lake breezes can develop parallel to the southeast shore of the lake when winds were too strong to allow development of a lake breeze on the eastern or western shores. The lines were 40-80 km long and tangent to the coastline at a point where the general flow is tangent to the lake. Using satellite data, Purdom (1976) showed similar lines extending inland up to $200 \mathrm{~km}$ along bays on the Texas coast.

\section{b. Convection}

Byers and Rodebush (1948) found that convergence of sea breezes from two coasts was an important factor in a thunderstorm maximum in central Florida. On the Florida panhandle, where only one sea breeze is present, the convergence was smaller and less persistent. Pielke (1974) confirmed Byers and Rodebush's results by using a 3D numerical model to conclude that sea breezes and their interactions are a principal control on summertime convection in Florida.

In the Great Lakes region, Chandik and Lyons (1971) discussed several types of interactions that can occur between lake breezes and convective storms on southern 
Lake Michigan. The most common effect was for the lake to suppress convection. In one case, a squall line approaching from the west intensified as it encountered the lake breeze, but then dissipated rapidly. Thunderstorms forming on the lake-breeze front on the downwind side of the lake sometimes moved inland as a squall line. They also noted that the lakes had little effect on organized squall lines and that severe thunderstorms occasionally developed on lake-breeze fronts.

In summary, sea breezes and lake breezes are powerful generators of boundaries and these boundaries have been shown to be linked with convection in many areas. In this paper we will provide a more systematic account of the effects of lake breezes on severe weather in southern Ontario using several examples to illustrate the nature of boundaries produced by lake breezes in southern Ontario under different synoptic conditions and the resulting weather conditions.

\section{Examples}

The methodology in this paper follows that of Purdom (1976) in using Geostationary Operational Environmental Satellite (GOES) images to illustrate various features of lake breezes. We assume that persistent quasistationary lines that conform closely to coastlines are due to lake-breeze circulations or lake-breeze circulations interacting with the mean flow. We use sequences and time composites of images to illustrate such persistent lines. Ideally we would have supplemented the satellite and radar analyses with surface mesoanalyses, but the surface network in southern Ontario is not sufficiently dense to do so. In a few cases we are able to confirm, using data from a single station, that a cloud line is associated with a lake breeze.

Although there is no such thing as a "typical" case, the cases discussed below cover the most important lake-breeze effects on weather that occurs in southern Ontario. Among these, we try to illustrate changes to the interactions between the lake-breeze circulation and the mean flow as the mean flow increases.

Because lake breezes are forced by the solar cycle, local standard time $(\mathrm{EST}=\mathrm{UTC}-5)$ is used in this study. Solar noon occurs about 1230 EST in southwestern Ontario.

\section{a. Weak flow (2 August 1996)}

There are few days in the Great Lakes region with zero gradient flow, which would allow the development of "pure" lake breezes. Most examples we have seen are, like this case, days with a weak northwesterly flow. The development of clouds associated with lake breezes on such days is illustrated by a satellite image at 1402 EST 2 August 1996 (Fig. 3) when the lake-breeze circulations had reached their greatest inland penetration. Estimated positions of lake-breeze fronts are shown as

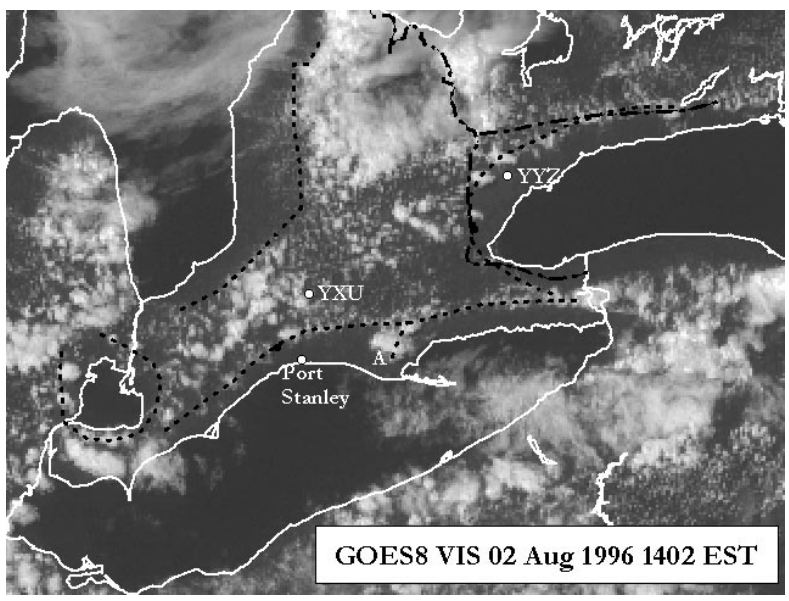

FIG. 3. GOES-8 visible satellite image at 1402 EST 2 Aug 1996. The Niagara Escarpment and Oak Ridges Moraine are marked by the dash-dot lines; the estimated positions of lake-breeze fronts by dotted lines. YYZ is Pearson Airport near Toronto and YXU is the London airport.

dotted lines; the Niagara Escarpment and Oak Ridges Moraine are indicated by dash-dot lines.

Well-developed lake-breeze circulations are evident near all the lakes. The greatest inland penetration (about $55 \mathrm{~km}$ ) is on the east side of Lake Huron where the lake breeze is assisted by the weak NW flow. The Lake Ontario lake breeze has moved inland up to $30 \mathrm{~km}$ and appears to be marked almost exactly by the Niagara Escarpment and the Oak Ridges Moraine. This is typical in weak flows and is likely related to interactions between terrain-induced circulations and lake breezes as discussed by Wexler (1946) and Estoque and Gross (1981).

North of Lake Erie, the front has penetrated about 15 $\mathrm{km}$ inland to the southwest of Port Stanley and $20 \mathrm{~km}$ inland to the east. Although the main front has moved farther inland, there must still be convergence on the peninsula at the head of Long Point Bay to support the thunderstorm there (indicated by A). On the Niagara Peninsula, the Ontario and Erie fronts appear to have merged.

Thunderstorms developed on the Lake Ontario front northwest of Pearson Airport (YYZ). These storms initially moved toward the NW, but as they grew into the flow aloft, they began moving toward the ESE and dissipated. Forecasters in Toronto have long noted the tendency for thunderstorms moving from the west to dissipate as they approach Pearson. They attributed this to downslope flow from the escarpment but an alternative explanation is that storms dissipate as they encounter lake-modified air.

This case illustrates most of the features seen on days with weak gradient flows. Next we discuss how the lakebreeze circulations are modified when interacting with a moderate SW gradient flow. 


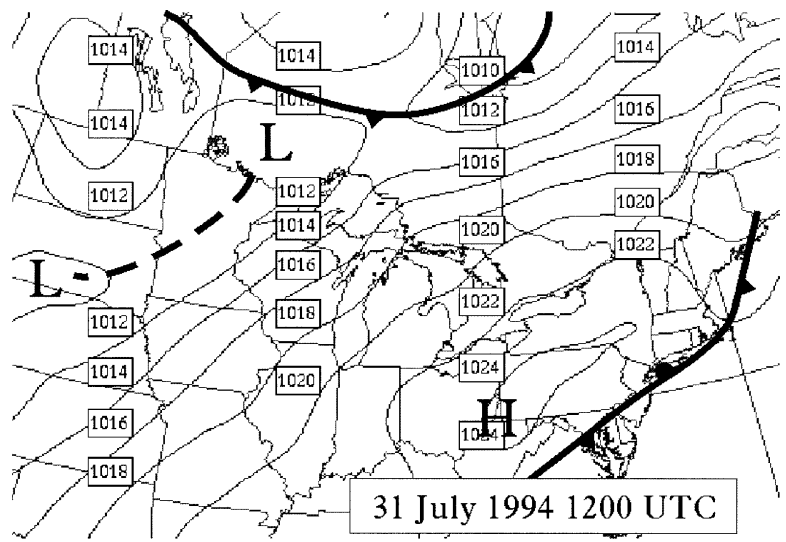

FIG. 4. Surface map at 1200 UTC (0700 EST) 31 Jul 1994. This map was extracted from the archive at the Canadian Meteorological Centre. Frontal positions were added based on the National Oceanic and Atmospheric Administration (NOAA) National Weather Service daily weather map series.

\section{b. Moderate SW flow (31 July 1994)}

This was a typical summer's day in southern Ontario: a moderate (about $6 \mathrm{~m} \mathrm{~s}^{-1}$ ) southwesterly flow between a high in Pennsylvania and a low in northwestern Ontario (Fig. 4) was bringing warm moist air over the region. By late morning, fair weather cumulus had developed over much of the area and thunderstorms developed along lake-breeze fronts.

Figure 5 is a composite of six GOES-7 visible images from 1000 to $1230 \mathrm{EST}$. The composite image highlights three regimes: clear skies over the lakes and in regions of onshore flow, generally cloudy skies inland with banding suggesting horizontal convective rolls, and enhanced convection associated with lake-breeze boundaries and topographical effects.

On the western half of Lake Erie, where the gradient wind was parallel to the coast, an apparent lake-breeze front (B-C in Fig. 5) developed near the coast and extended inland beyond Woodstock. The lake-breeze front showed no further inland motion once it had formed. East of Port Stanley, where the winds were onshore, there was enhanced convection parallel to the coast and about $40 \mathrm{~km}$ inland (from point $\mathrm{C}$ to $\mathrm{E}$ ).

These two branches evolved differently. On the eastern branch, clouds formed first on east-west shorelines at about 0800 EST. The area north of the coastline filled with cumulus cloud over the next $2 \mathrm{~h}$ and by about 1000 EST a line of more intense cumulus formed along the line $\mathrm{C}-\mathrm{E}$. This line reached its maximum strength at about 1100 EST (according to data from the King radar, located $40 \mathrm{~km}$ north of Toronto; see Fig. 2) and then dissipated. This line did not form at the lakeshore and move inland; it formed in place. From watching animations, it appears that cloud elements traveled inland along horizontal convective rolls and became enhanced as they reached line $\mathrm{C}-\mathrm{E}$. We speculate that the gradient flow had advected lake air inland and the convection

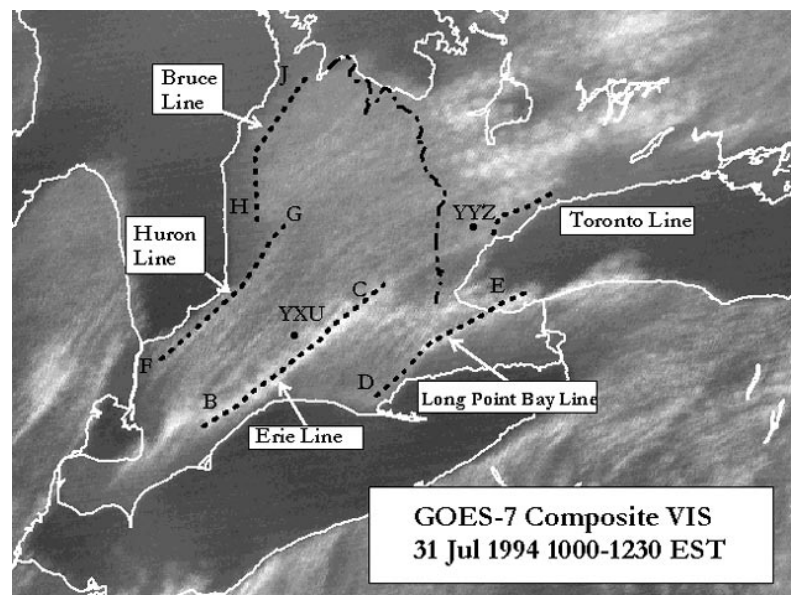

FIG. 5. Composite GOES-7 visible image at 1000-1230 EST 31 Jul 1994. This image is the average of six visible images at half-hour intervals from 1000 to 1230 EST. Significant boundaries discussed in the text are marked by letters and dotted lines. The dash-dot line is the Niagara Escarpment.

developed on a boundary between lake-modified air and unmodified air, perhaps on an internal boundary layer as discussed by Finkele et al. (1995).

Convection on the western branch $(\mathrm{B}-\mathrm{C})$ developed more slowly with clouds first forming at about 0900 EST. Clouds developed slowly at first and then very rapidly after $1100 \mathrm{EST}$, about the same time as the eastern branch was dissipating. No severe weather was reported but there were brief heavy downpours of up to $15 \mathrm{~mm}$ of rain.

The NE-SW-oriented coast at the head of Long Point Bay also generated a line extending inland to meet the eastern branch of the main front (D-E). This line is a frequent feature in satellite images under moderate prevailing southwest flows and appears to be an inland extension of the convection that forms on this peninsula on days with weaker flows.

Convergence lines associated with Lake Huron were much less developed in satellite imagery. Some enhanced convection can be seen between Sarnia and Grand Bend (line $\mathrm{F}-\mathrm{G}$ ) and extending inland. Farther north, the line $\mathrm{H}-\mathrm{J}$ marks a transition from cloud-free skies to banded clouds oriented with the winds; there was no enhanced convection with this line. A strong thunderstorm did form near Grand Bend at about 1500 EST when outflow from a storm on the Erie line collided with the Huron line. This storm produced heavy rain as it moved northeast.

Since the winds are parallel to the Lake Erie coast west of Port Stanley, Estoque's (1962) model would suggest an onshore friction-induced component on the Canadian side of Lake Erie and an offshore component on the U.S. side. This appears to be the case since the front forms inland on the Canadian side and clouds go right to the shoreline on the American side. Estoque's model also predicts stronger vertical velocities on the 


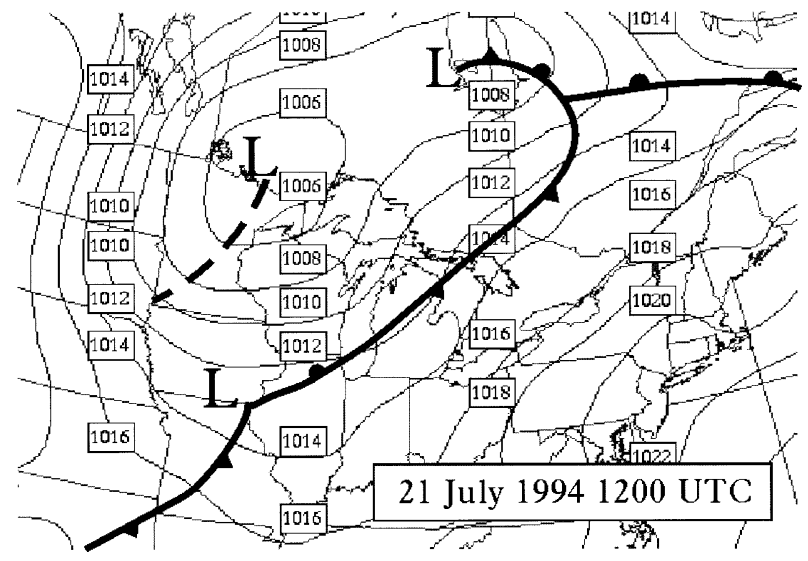

FIG. 6. Surface map at 1200 UTC (0700 EST) 21 Jul 1994.

U.S. side. We modeled this case using the Mesoscale Compressible Community model (MC2; Benoit et al. 1997) and it showed much stronger vertical velocities on the U.S. side. Similar arguments suggest that the stronger vertical velocities should be on the front on the Huron side of the isthmus. If cloud development can be used as a surrogate for the strength of the front, just the opposite seems to be the case. Perhaps other factors such as moisture availability may be important but generally we have observed that the Erie front is more active than the Huron front when there is no larger-scale synoptic forcing. Significant developments seem to occur on the Huron front more often when there are interactions with the Erie front or with other features such as cold fronts.

The behavior of the lake breezes on the Niagara Peninsula bears special mention. In the weak flow case, the Erie and Ontario fronts merged in the center of the peninsula. In this case, there appears to be a merged Erie-Ontario front just offshore on Lake Ontario. According to satellite data, the cloud line first formed right along the shoreline and by the time radar indicated rain from the cells, it had been pushed offshore. This behavior is consistent with the modeling of both Estoque and Gross (1981) and Comer and McKendry (1993). Although their model domains included only the eastern end of Lake Erie, both models showed the Erie breeze merging with the Ontario breeze near the southern shore of Lake Ontario.

North of Lake Ontario the situation is more complex. In the composite image a persistent line of convection is evident running along the Oak Ridges Moraine east from the escarpment. This line developed suddenly at about 1100 EST with no indications of a cloud line having moved inland. As in the weak flow case, complex interactions between terrain-induced circulations and the lake breeze are likely responsible. Clouds developed on the east side of the escarpment, apparently in an area of gravity-wave-induced upward motion, and moved eastward. Modeling of this day using the MC2 model at $10-\mathrm{km}$ horizontal resolution indicated that a gravity wave formed in the southwest flow over the escarpment

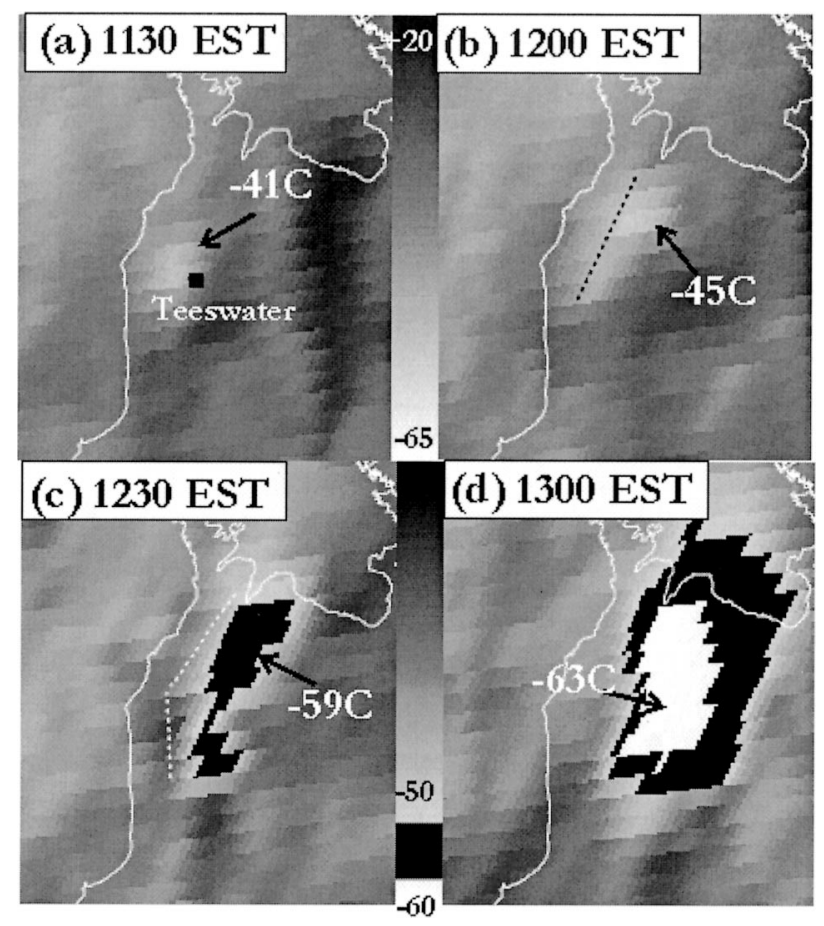

FIG. 7. Sequence of GOES-7 infrared images on 21 Jul 1994: (a) 1130, (b) 1200, (c) 1230, and (d) 1300 EST. The same temperature scale, indicated between the images, was used for all figures. In (c) and (d) temperatures in the range of $-50^{\circ}$ to $-60^{\circ} \mathrm{C}$ are highlighted in black. The coldest temperature is indicated in each image.

with downward motion in the lee and an area of upward motion farther east, consistent with the cloud patterns observed.

The boundaries highlighted in Fig. 5 will be used in section 5 to explain patterns in the tornado climatology of southern Ontario. In the next section we discuss the interaction of cold fronts with lake breezes.

\section{c. Moderate to strong $S W$ flow interacting with a cold front (21 July 1994)}

The synoptic situation at 0700 EST on 21 July 1994 is shown in Fig. 6. There was a moderate to strong (about $10 \mathrm{~m} \mathrm{~s}^{-1}$ ) southwest flow ahead of a cold front crossing Michigan.

As it crossed Lake Huron, the front was marked by a continuous cloud band along the front with coldest cloud-top temperatures of about $-28^{\circ} \mathrm{C}$. The development of deep convection on the cold front from 1130 to 1330 EST is shown in Fig. 7. After the front crossed the eastern shore of the lake a sharp increase in the GOES-7 reflectivity and a drop in the IR brightness temperature to $-41^{\circ} \mathrm{C}$ indicated the development of a strong cell near Teeswater. By 1230 EST, the line of colder tops had extended farther northeast and by 1300 EST cloud-top temperatures were nearing $-60^{\circ} \mathrm{C}$. By $1300 \mathrm{EST}$, the rapid expansion of the $-50^{\circ} \mathrm{C}$ isotherm shows that the anvil had been swept eastward up to 80 


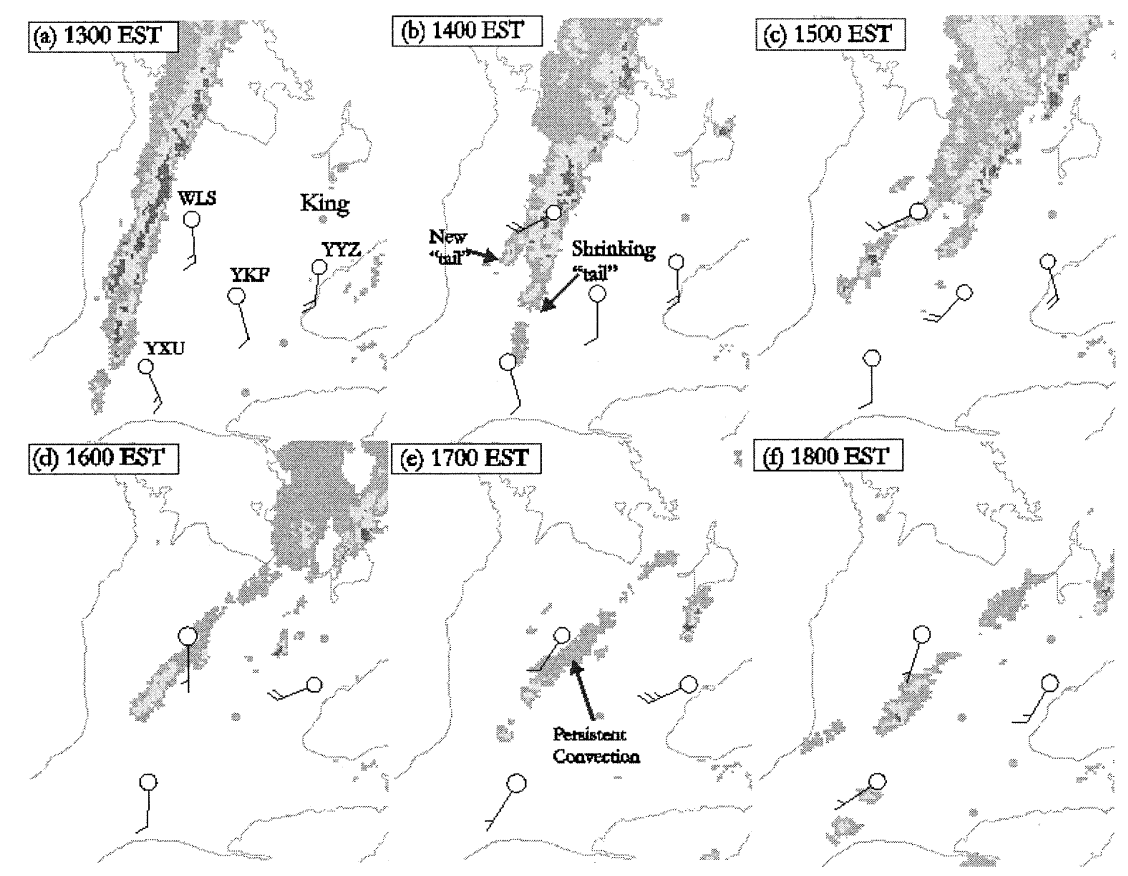

FIG. 8. King radar images on 21 Jul 1994: (a) 1300, (b) 1400, (c) 1500, (d) 1600, (e) 1700, and (f) 1800 EST. The rain rate is indicated by the gray scale: medium gray, $\leq 1 \mathrm{~mm} \mathrm{~h}^{-1}$; light gray, between 1 and $32 \mathrm{~mm} \mathrm{~h}^{-1}$; dark gray, $\geq 32 \mathrm{~mm} \mathrm{~h}^{-1}$. Hourly wind observations are indicated for Mount Forest (WLS), London (YXU), Kitchener (YKF), and Toronto Pearson (YYZ).

$\mathrm{km}$. The dashed white line is the Lake Huron lake-breeze boundary, as in Fig. $5(\mathrm{~J}-\mathrm{K})$. Although surface data are not available to confirm the exact location of the lakebreeze boundary, it seems likely that the explosion in convection was due to the interaction of the cold front with the lake breeze.

Figure 8 is a series of King radar images at hourly intervals from 1300 to 1800 EST. Initially, the front was

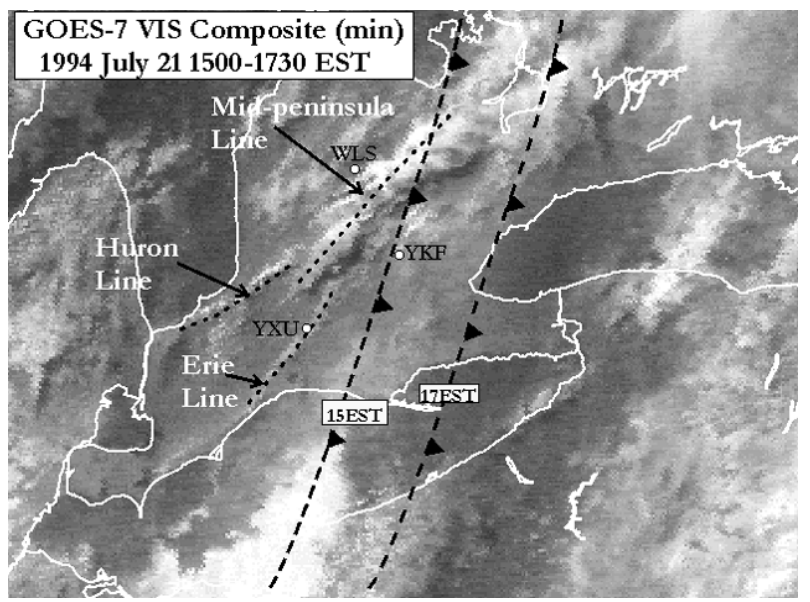

FIG. 9. Minimum composite of GOES-7 images from 1500 to 1730 EST on 21 Jul 1994. The image was formed by finding the minimum brightness of the six images at each pixel. Thus gray areas indicate the presence of cloud in each of the six images and, hence, persistence of convection at that location. marked by a continuous narrow band of heavy ( $\geq 64$ $\mathrm{mm} \mathrm{h}^{-1}$ ) precipitation. By $1400 \mathrm{EST}$, the beginnings of a line building back toward Grand Bend, Ontario, are evident. As this line grows over the next hour, the original line shrinks to the northeast. By the end of the period, an inverted-Y structure is present with two arms extending along the coastlines, apparently merging in a midpeninsula line. The midpeninsula line was quasi stationary for $4 \mathrm{~h}$ and produced up to $70 \mathrm{~mm}$ of rain.

Surface wind observations are plotted at four stations. At Mount Forest, Ontario (WLS), both temperature and dewpoint dropped sharply between 1300 and 1400 EST as the wind shifted to the southwest, indicating a cold frontal passage. A brief shower occurred at London, Ontario (YXU), as the cloud line passed the station but the winds remained southerly. Farther south Cleveland, Ohio, reported a thunderstorm and a temperature drop of $8^{\circ} \mathrm{C}$ as the wind shifted to the southwest. An hour later at Kitchener, Ontario (YKF), the winds shifted to the southwest and the dewpoint dropped slightly but the temperature remained constant. Later at Toronto's Pearson Airport (YYZ), the winds shifted to the southwest but there was little change in temperature or dewpoint. From theses observations it appears that at least the Erie branch of the lake-breeze circulation maintained itself as the cold front passed through.

Figure 9 is a minimum reflectivity composite of six GOES-7 visible images from 1500 to 1730 EST. Since each pixel shows the minimum reflectivity from the six 


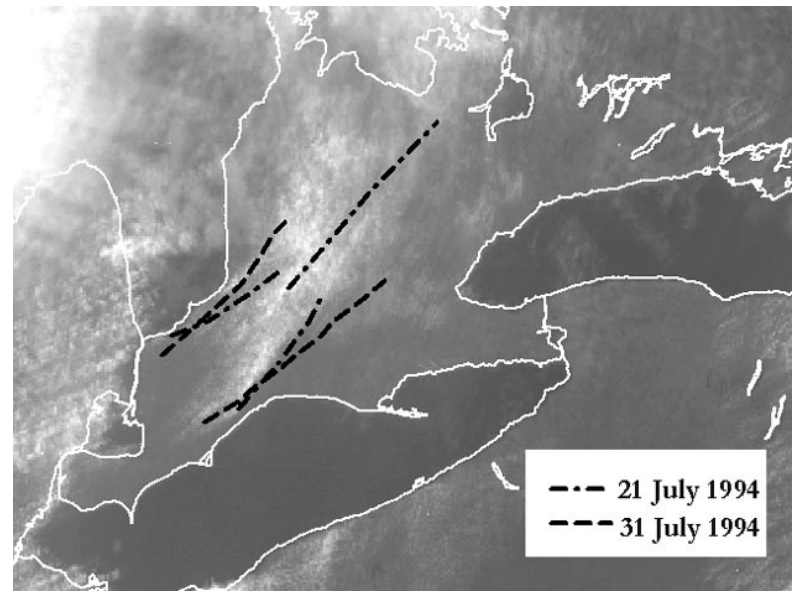

FIG. 10. Comparison of cloud boundaries from $21 \mathrm{Jul}$ (dash-dot) and $31 \mathrm{Jul}$ (dash) 1994. The background image is a mean composite of six GOES-8 visible images from 22 Aug 1996, another day with a moderate southwest flow. Note the similarity in boundaries on that day also.

images, this figure highlights locations where clouds persisted for the entire period. The bright white areas extending into Lake Erie and the northeast from Lake Simcoe are from deep convection associated with the cold front. Narrow lines parallel to the coasts of Lakes Huron and Erie, which merged into the midpeninsula line, were persistent over a 3 -h period. Although more surface observations would be useful, it appears from radar and satellite imagery that the inverted-Y structure was a merger of Erie and Huron lake-breeze circulations and that this circulation either maintained itself or was quickly reestablished in spite of the cold frontal passage. This seems curious, but Pielke (1974) noted that sea breezes are reestablished quickly after cold frontal passages in Florida.

In this case, unlike that of 31 July, no east-west line develops north of Lake Erie (cf. line C-E in Fig. 5). The gradient wind on 21 July was about $10 \mathrm{~m} \mathrm{~s}^{-1}$ compared to about $6 \mathrm{~m} \mathrm{~s}^{-1}$ on 31 July. Modeling results (Arritt 1992) suggest that convergence lines will not form in onshore flows when the onshore flow exceeds some threshold between 3.5 and $7.5 \mathrm{~m} \mathrm{~s}^{-1}$. Since the east-west line dissipated after a few hours on 31 July, the onshore gradient was probably near the threshold for formation of a convergence line, in agreement with Arritt's result. Although the boundary breaks down in moderate onshore flows, the branch parallel to the coast tends to persist and extend farther inland.

The other major difference between the two cases is the merger of the Huron and Erie lines in a midpeninsula line, as illustrated in Fig. 10. The background in Fig. 10 is a composite GOES-8 visible image from 1200 to 1400 EST on 22 August 1996, showing boundaries in similar locations with the hint of a midpeninsula line. It is uncertain under what conditions mergers occur. During ELBOW 1997, a quasi-stationary multicellular cluster formed at the apparent merger of the Huron and Erie lines. Modeling with MC2 (Sills and King 1998; Qiu 2002) and visual observations suggest that when convection formed between the two lines, they began to approach each other. Further modeling work is required to establish the conditions for such mergers.

Finally, in Fig. 11 we compare the cloud patterns from

\section{Jul 19941430 EST}



\section{May 19851500 EST}

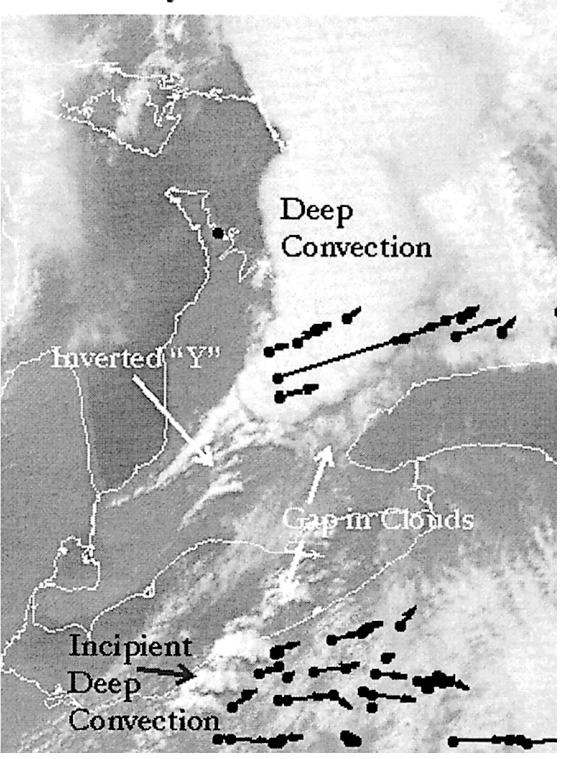

FIG. 11. Comparison of cloud patterns between 21 Jul 1994 and 31 May 1985, the day of a major tornado outbreak in Ontario and Pennsylvania-Ohio. 


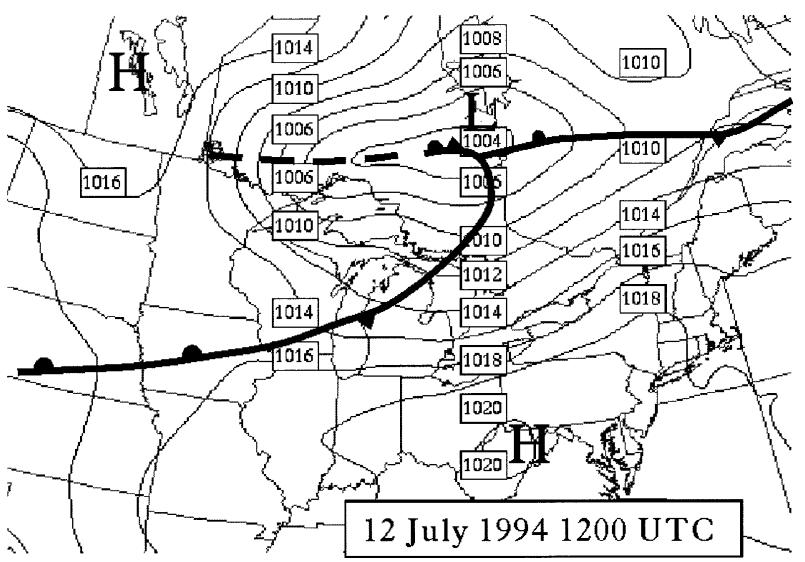

FIG. 12. Surface map at 1200 UTC (0700 EST) 12 Jul 1994. This map was extracted from the archive at the Canadian Meteorological Centre. Frontal positions were added based on the NOAA National Weather Service daily weather map series.

the 21 July case with those of 31 May 1985, the day of a major tornado outbreak in Ontario, Ohio, and Pennsylvania. There is a remarkable similarity of cloud patterns on the two days: explosive convection in the north, seemingly fed by an inverted-Y structure of lower level clouds, and the beginnings of deep convection in Ohio extending into Lake Erie. The similarity in the cloud structure suggests that boundary layer mesoscale processes played a similar role on both days. It is also plausible that lake breezes played a role in suppressing tornadoes to the north of Lake Erie and hence may in part determine where tornadoes are likely to form in southern Ontario. We will expand on this theme in section 5 where we look at the spatial distribution of tornado touchdown points in southern Ontario.

\section{d. Moderate WSW flow (12 July 1994)}

When the surface winds become more westerly, the area of interest shifts toward the London area, as in the case discussed by King (1996) previously. A low pressure center (Fig. 12) north of Lake Huron was moving toward Quebec and a weak cold front was sinking slowly southward across the Great Lakes. The upper flow was westerly at all levels.

A thin layer of stratocumulus (tops about $1000 \mathrm{~m}$ above ground, estimated from radiosonde and satellite data) covered most of southwestern Ontario and lower Michigan. As the morning progressed, the clouds in Michigan became banded in a NNE-SSW orientation.

One of the bands became enhanced as it reached the southern end of Lake Huron at 1200 EST. At the same time, a band of clouds was moving inland from Lake Erie. By 1330 EST (Fig. 13), the Erie line was approaching the Huron line and a large thunderstorm had developed just NE of London (YXU) on the Huron line. The first radar echo appeared at 1310 EST and echo tops had reached $12 \mathrm{~km}$ by $1320 \mathrm{EST}$. The coldest

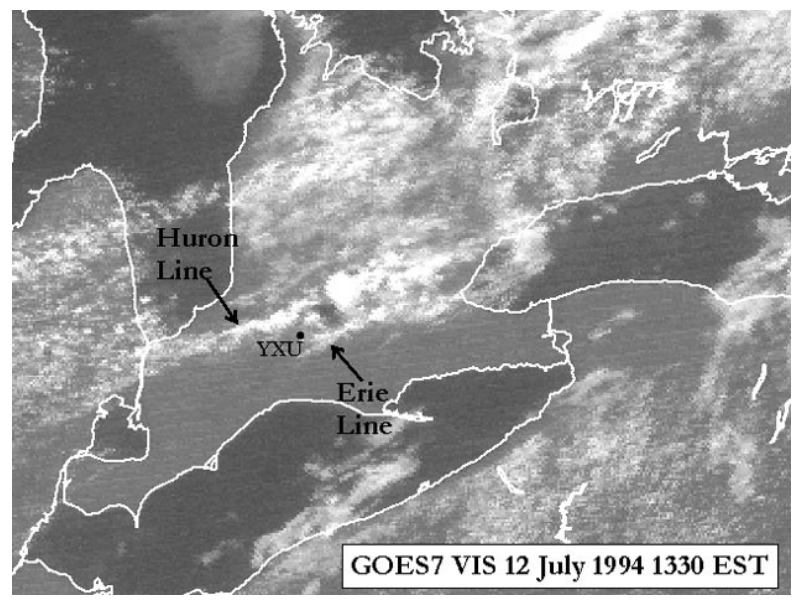

FIG. 13. GOES-7 visible image at 1330 EST 12 Jul 1994.

GOES-7 cloud-top temperature dropped from $3{ }^{\circ} \mathrm{C}$ at $1300 \mathrm{EST}$ to $-50^{\circ} \mathrm{C}$ at $1430 \mathrm{EST}$. The data from the London airport indicated a lake-breeze passage at about 1600 EST as the winds shifted from westerly to southerly and the temperature dropped from $27^{\circ}$ to $23^{\circ} \mathrm{C}$.

Over a 6-h period, the western end of the band remained fixed while the eastern end rotated southward slightly. After 1900 EST, the whole line began to move slowly southward across Lake Erie, presumably as the Erie lake breeze weakened.

Severe weather occurred in the form of strong winds, heavy rain, and golfball-sized hail. The maximum recorded rainfall was $104 \mathrm{~mm}$ about $30 \mathrm{~km}$ southeast of London. London reported thunder continuously for $9 \mathrm{~h}$ (with two short gaps) during this event.

According to the 0700 EST sounding at White Lake, Michigan (DTX), the convective temperature necessary to break a sharp capping inversion was $30^{\circ} \mathrm{C}$. High temperatures in southern Ontario reached $27^{\circ}-28^{\circ} \mathrm{C}$. The only convection to occur was with the lake-breeze merger, suggesting that lake breezes provided sufficient moisture convergence or lift or both to break the inversion, even though temperatures did not appear to have reached the convective temperature.

The interaction of convergence lines in the London area appears to be the most repeatable lake-breeze interaction, occurring several times per year. Similar events happened on two other occasions in July 1994. Another similar case occurred near Komoka, Ontario, just west of London during ELBOW 1997 (King et al. 1999) when thunderstorms continually redeveloped at the merger point of two lines for about $2 \mathrm{~h}$.

\section{e. Light to moderate NNW flow (14 August 1993)}

The most common surface wind direction in southern Ontario in the summer is NW (Comer and McKendry 1993). In this section, we briefly discuss convection patterns in such cases. When the surface flow is from the NW, most significant convection is in southeastern 


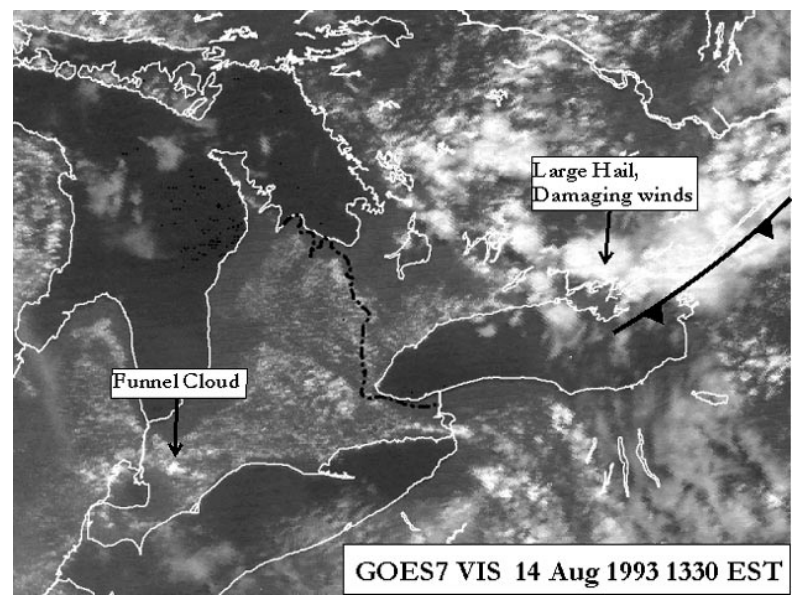

FIG. 14. GOES-7 visible image at 1330 EST 14 Aug 1993. The cold frontal position is based on the daily weather map series.

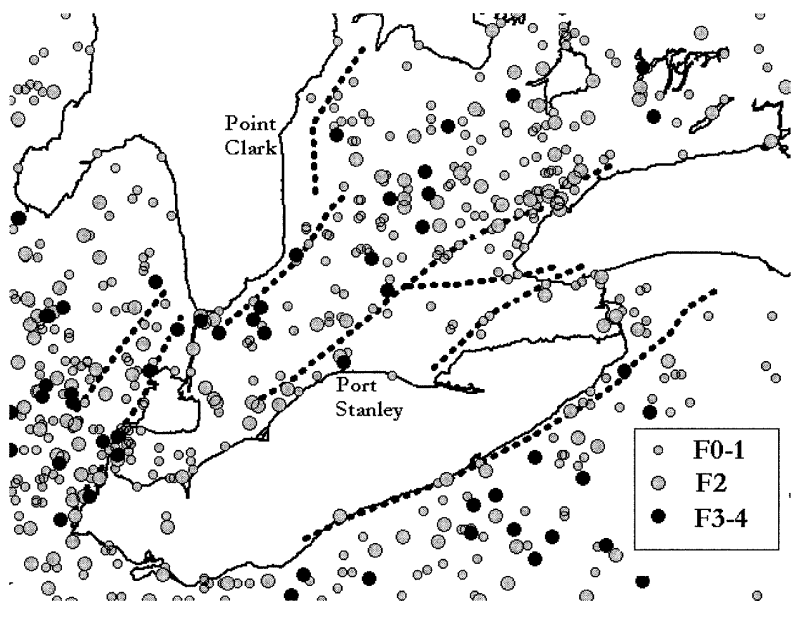

FIG. 15. Touchdown points of confirmed and probable tornadoes from 1917 to 1992 during the afternoon (1200-2000 EST). The dashed lines are the convergence lines noted on 31 Jul 1994 (Fig. 5).

\section{Tornado climatology}

We have noted several cases of severe weather associated with lake-breeze interactions. KLM96 demonstrated a link between lake breezes and the tornado climatology of southern Ontario. The ideas first presented there will be developed further in this section. We will also use the 21 July 1994 case above as a conceptual model to explain the location of major tornado outbreaks in southwestern Ontario.

The Canadian tornado database was assembled by Newark (1984) and currently covers the period from 1917 to 1992 . It classifies events as confirmed, probable, or possible tornadoes based on a number of criteria. In this study only events in the confirmed and probable categories are used; a few of the probable events that appear to have been derechoes were also omitted. We have further restricted the data to afternoons (12002000 EST) from April to September when lake breezes are most likely to occur.

Touchdown points for confirmed and probable warm season afternoon tornadoes are shown in Fig. 15. Although there are differences in how the tornado data are collected, we have plotted adjacent U.S. data for comparison.

The greatest density of tornado touchdowns appears to be in southwest lower Michigan, extending into western Essex County in Ontario. On the U.S. side of Lake Erie, the distribution of touchdown points is fairly uniform and extends right to the shoreline. In contrast, on the Ontario side of Lake Erie there is a marked variation in tornado distribution. West of Port Stanley there is a concentration of events, including several F2 tornadoes and one F3, right along the shoreline. East of Port Stanley, there has never been an F2 or stronger tornado event and the few weak events there are clustered along the Long Point Bay line. For one of these events (17 June 


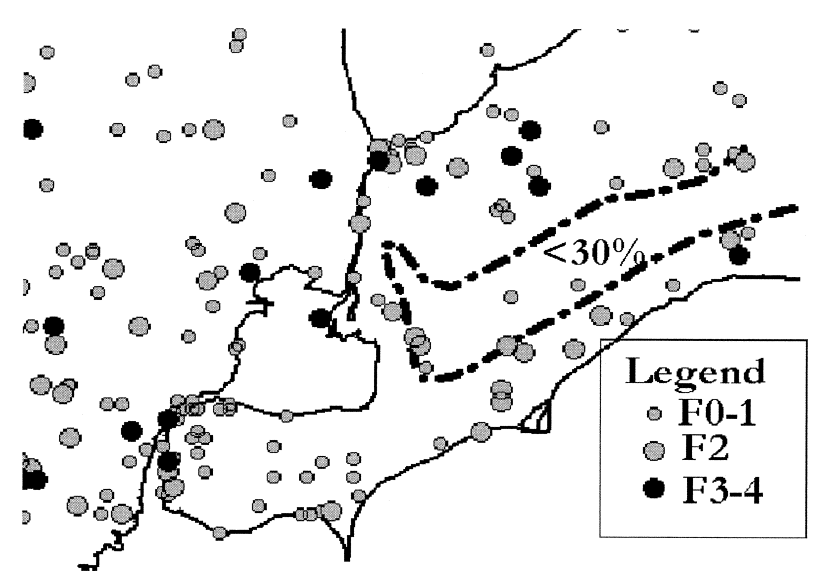

FIG. 16. Distribution of tornado touchdown points in the interlake region between Lakes Erie and Huron. The dashed line is the $30 \%$ probability of lake-breeze occurrence line from Sills (1998). The legend gives the classification of the tornadoes.

1992), satellite imagery clearly showed a persistent Long Point Bay line and the tornado occurred when a cold front crossed that location.

The eastern shore of Lake Huron shows a similar pattern to that north of Lake Erie. South of Point Clark there is an absence of events extending inland for about $40 \mathrm{~km}$, but north of Point Clark there is a minor maximum in southern Bruce County, exactly the line where deep convection was set off on 21 July 1994 (Fig. 7).

On the north shore of Lake Ontario east of Toronto, only a handful of weak events have occurred to the south of the Oak Ridges Moraine. These events have occurred mostly in NW flows.

Overall, there is a remarkable correspondence between the boundaries evident in the composite visible image for 31 July 1994 (dashed lines from Fig. 5) and tornado touchdown points: where southwest winds are onshore, there is an absence of events, while concentrations are found along the apparent convergence lines. This suggests that tornadoes are suppressed in lakemodified air and may be enhanced at lake-breeze boundaries.

Figure 16 shows tornado touchdown points in extreme southwestern Ontario in more detail. The dashdot line is the $30 \%$ probability of lake-breeze occurrence isopleth from Sills (1998), which almost exactly separates an area with almost no tornadoes from an area of dense concentration. In other words, a lower probability of lake breezes coincides with a minimum of tornadoes.

King (1997) found that the tornado density in a line from Lake St. Clair to Lake Simcoe was about 3 times higher than a more populated area just to the south. We will extend this analysis by showing regional variations of tornadoes in southwestern Ontario using a grid skewed to conform to the orientation of the coastlines. The grid is shown in Fig. 17 along with F3 and F4 touchdown points and the persistent cloud lines from 21 July 1994 (dashed lines). The bold arrows are vector

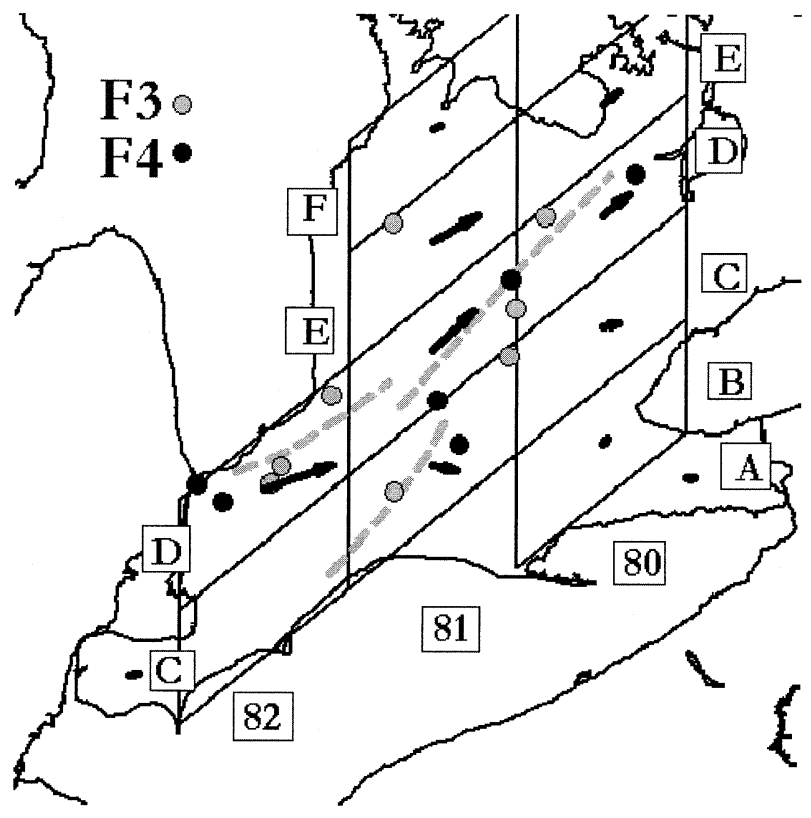

FIG. 17. Regional characteristics of tornadoes. The north-south lines are meridians of longitude; the skewed lines were chosen to be parallel to the Lakes Erie and Huron coastlines. The skewed boxes are approximately $100 \mathrm{~km}$ by $40 \mathrm{~km}$. The heavy arrow is the vector mean of all tornadoes with tracks in a given box. The dashed lines are the apparent convergence lines (Huron, Erie, and midpeninsula) from 21 Jul 1994 (see Fig. 9).

averages of the storm tracks for all events (of any strength and with a known track) in that box. Table 1 contains information from Fig. 17 and further breakdowns according to Fujita scale and track lengths.

Several features stand out in Fig. 17. The longest average tracks are in the D boxes stretching from Lake St. Clair to Lake Simcoe, which contain both the Huron and midpeninsula lines from 21 July 1994. Box E81 also has a long average track, possibly associated with a convergence line, which often extends NE from Point Clark. In contrast, average track lengths for the boxes immediately north of Lake Erie are much shorter, averaging about 3-4 km except for box C81. This latter box is crossed by the Erie line and the average was due to two events with tracks longer than $20 \mathrm{~km}$. Results using the median (Table 1) instead of average track length were similar.

There is also a difference in direction of storm motion evident in Fig. 17. In Table 1, the Lake Huron boxes (D81-82, E81) have 28 events with tracks from the southwest as opposed to 4 from the northwest. For boxes C80-81, the SW/NW ratio is $12 / 14$ and for the Lake Erie boxes it is $10 / 5$. It appears that the farther one is from Lake Huron, the more likely a tornado track is from the northwest. This may be related to the suppression of convection in the lee of Lake Huron in northwest flows.

If we now consider only the strongest events, we see in Fig. 17 that most long-track F3 and F4 events touched 
TABLE 1. Statistics for tornadoes by F category for grid boxes in Fig. 14.

\begin{tabular}{|c|c|c|c|c|c|c|c|c|c|c|c|c|}
\hline Region & F0 & F1 & $\mathrm{F} 2$ & F3 & F4 & Total & $\begin{array}{l}\text { With } \\
\text { track }\end{array}$ & $\begin{array}{l}\text { Avg direction } \\
\text { and track } \\
\text { length }(\mathrm{km})\end{array}$ & SW/NW & $\begin{array}{l}\text { Median } \\
\text { length } \\
(\mathrm{km})\end{array}$ & $\begin{array}{l}\text { No. with } \\
\text { track } \\
>10 \mathrm{~km}\end{array}$ & $\begin{array}{l}\text { No. with } \\
\text { track } \\
>20 \mathrm{~km}\end{array}$ \\
\hline A 80 & 5 & 0 & 1 & 0 & 0 & 6 & 5 & $270 / 3.3$ & $4 / 1$ & 3 & 1 & 0 \\
\hline B81 & 1 & 0 & 0 & 0 & 0 & 1 & 1 & $230 / 1.0$ & $0 / 0$ & 1 & 0 & 0 \\
\hline B80 & 12 & 1 & 0 & 0 & 0 & 13 & 4 & $243 / 4.0$ & $2 / 2$ & 2.6 & 1 & 0 \\
\hline $\mathrm{C} 83$ & 8 & 5 & 2 & 0 & 1 & 16 & 6 & $270 / 5.1$ & $4 / 2$ & 3.6 & 1 & 0 \\
\hline $\mathrm{C} 82$ & 2 & 0 & 1 & 0 & 0 & 3 & 0 & 0 & $0 / 0$ & 0 & 0 & 0 \\
\hline C81 & 3 & 2 & 2 & 3 & 1 & 11 & 7 & $280 / 12.2$ & $4 / 3$ & 4.3 & 2 & 2 \\
\hline $\mathrm{C} 80$ & 14 & 9 & 4 & 0 & 0 & 27 & 20 & $257 / 8.2$ & $8 / 11$ & 7.1 & 6 & 3 \\
\hline D82 & 4 & 6 & 3 & 4 & 2 & 19 & 12 & $250 / 34.1$ & $11 / 1$ & 14.2 & 7 & 6 \\
\hline D81 & 7 & 6 & 2 & 2 & 2 & 19 & 14 & $226 / 27.1$ & $12 / 3$ & 8.6 & 7 & 4 \\
\hline D80 & 7 & 3 & 6 & 1 & 1 & 18 & 7 & $230 / 16.5$ & $3 / 4$ & 12.1 & 2 & 2 \\
\hline E81 & 2 & 2 & 1 & 1 & 0 & 6 & 4 & $240 / 24.2$ & $5 / 0$ & 15.6 & 3 & 1 \\
\hline E80 & 3 & 0 & 0 & 0 & 0 & 3 & 2 & $230 / 10.0$ & $0 / 2$ & 7.8 & 1 & 0 \\
\hline F81 & 5 & 1 & 1 & 0 & 0 & 7 & 3 & $240 / 3.2$ & $2 / 1$ & 3.7 & 0 & 0 \\
\hline
\end{tabular}

down near the 21 July 1994 lines. In fact, all occurred within $20 \mathrm{~km}$ of these lines; for F3 tornadoes the average distance was $10 \mathrm{~km}$ and for F4 tornadoes it was $7 \mathrm{~km}$. Markowski et al. (1998) showed that $70 \%$ of tornadoes during the Verification of the Origin of Rotation in Tornadoes Experiment (VORTEX-95) occurred within 30 $\mathrm{km}$ of a low-level boundary. The close correspondence between tornado touchdowns in southern Ontario along lines where we have frequently seen lake-breeze convergence lines suggests that similar processes may be at work here.

\section{Discussion and conclusions}

We have demonstrated characteristic cloud patterns, apparently related to lake-breeze circulations, which often occur in southwestern Ontario and have shown patterns in tornado touchdowns that have intriguing similarities. Because of lack of data we are unable to make a definite causal connection.

Wilson and Schreiber (1986) found that almost 80\% of convective storms in Colorado formed on preexisting boundaries and that many of these boundaries were due to topography. Since lake breezes generate boundaries similar to the patterns we see in tornado touchdowns, we suspect that a large portion of the severe thunderstorms, including tornadic storms, in southern Ontario form on lake-breeze boundaries. Most of these cases are examples of mesoscale circulations triggering events set up by larger-scale processes, as discussed by Doswell (1987).

Doppler radar research in the 1970 s showed that tornadoes were normally associated with mesocyclone or supercell thunderstorms. In the late 1980s, Brady and Szoke (1989) and Wakimoto and Wilson (1989) documented cases in which tornadoes formed from nonsupercell thunderstorms (called landspouts). Both processes seem to be important in Ontario.

Long-track storms, which are most likely supercells, occur preferentially along the Lake St. Clair to Lake Simcoe corridor. We propose the 21 July 1994 case as a model to explain this pattern. On such days a pattern of merging lake breezes forms ahead of an approaching cold front. The lake-breeze circulation could play two roles by increasing moisture convergence and increasing low-level shear, both of which are important in tornado development. If the environmental conditions were otherwise favorable for the development of supercells and subsequently tornadoes, the lake-breeze circulations may provide the trigger.

Somewhat contrary to expectations, events near Lake Erie tend to have shorter tracks and more variable directions of travel than events in the Lake St. Clair to Lake Simcoe corridor. Sills and King (2000) documented an apparent landspout in this region and listed several events that also appear to have been landspouts. Since long-track events are confined mainly to the Lake St. Clair to Lake Simcoe corridor, many of the events farther south may have been landspouts. Lake-breeze boundaries would provide a favorable environment by increasing moisture and low-level vorticity.

The evidence presented here strongly suggests that in southern Ontario lake breezes may provide low-level boundaries on which tornadoes may form and that the 21 July 1994 case can be used as a model to explain major tornado outbreaks in southern Ontario. The synoptic situation that favors tornado outbreaks in southwestern Ontario is a southwesterly flow ahead of a strong cold front. Clear skies are generally needed ahead of the cold front to enhance buoyant energy. This, of course, is also the recipe for lake-breeze convergence lines. When the cold front encounters the convergence lines, the additional moisture convergence and low-level vorticity may provide a trigger for tornado formation.

We feel that we have provided a good case for a link between lake breezes and tornadoes but the lack of data has made confirmation difficult. ELBOW 1997 (King et al. 1999) was conceived to provide such confirmation but was limited by resources. ELBOW 2001 (Sills et al. 2002) was conducted in the summer of 2001 employing Doppler radar, research aircraft, a more extensive surface network, and chase teams. Data from this 
project will be used to improve our understanding of interactions between lake-breeze fronts and synopticscale weather features and their role in severe weather in southern Ontario.

Acknowledgments. Alejandro Aldunate was for many years a stalwart in satellite meteorology in Canada, supporting both operational meteorology and research projects, including this work. This paper is dedicated to his memory. We also wish to acknowledge the support of forecasters at the Regional Centre, Toronto. Brian Clark and Bill Chang provided computer support. Cathy Banic provided encouragement. The reviewers made many suggestions that substantially improved this paper.

\section{REFERENCES}

Arritt, R. W., 1993: Effects of the large-scale flow on characteristic features of the sea breeze. J. Appl. Meteor., 32, 116-125.

Benoit, R., M. Desgagne, P. Pellerin, S. Pellerin, Y. Chartier, and S. Desjardins, 1997: The Canadian MC2: A semi-Lagrangian, semiimplicit wideband atmospheric model suited for finescale process studies and simulation. Mon. Wea. Rev., 125, 2382-2415.

Brady, R. H., and E. J. Szoke, 1989: A case study of nonmesocyclone tornado development in northeast Colorado: Similarities to waterspout formation. Mon. Wea. Rev., 117, 843-856.

Burrows, W. R., 1991: Objective guidance for 0-24-hour and 2448-hour mesoscale forecasts of lake-effect snow using CART. Wea. Forecasting, 6, 357-378.

Byers, H. R., and H. R. Rodebush, 1948: Causes of thunderstorms of the Florida peninsula. J. Meteor., 5, 275-280.

Chandik, J. F., and W. A. Lyons, 1971: Thunderstorms and the lake breeze front. Proc. Seventh Conf. on Severe Storms, Kansas City, MO, Amer. Meteor. Soc., 218-225.

Clodman, S., and W. Chisholm, 1994: High lightning flash density storms in the southern Great Lakes region. Natl. Wea. Dig., 19, $34-44$.

_, and —_, 1996: Lightning flash climatology in the southern Great Lakes region. Atmos.-Ocean, 31, 481-499.

Comer, N. T., and I. G. McKendry, 1993: Observations and numerical modeling of Lake Ontario lake breezes. Atmos.-Ocean, 31, 481499.

Daggupaty, S. M., 2001: A case study of the simultaneous development of multiple lake-breeze fronts with a boundary layer forecast model. J. Appl. Meteor., 40, 289-311.

Doswell, C. A., III, 1987: The distinction between large-scale and mesoscale contribution to severe convection: A case study example. Wea. Forecasting, 2, 3-16.

Estoque, M. A., 1962: The sea breeze as a function of the prevailing synoptic situation. J. Atmos. Sci., 19, 244-250.

_, 1981: Further studies of a lake breeze. Part I: Observational study. Mon. Wea. Rev., 109, 611-618.

- and J. M. Gross, 1981: Further studies of a lake breeze. Part II: Theoretical study. Mon. Wea. Rev., 109, 619-634.

Finkele, K., J. M. Hacker, H. Kraus, and R. A. D. Byron-Scott, 1995 A complete sea-breeze circulation cell derived from aircraft observations. Bound.-Layer Meteor., 73, 299-317.

King, P., 1996: A long-lasting squall line induced by interacting lake breezes. Preprints, 18th Conf. on Severe Local Storms, San Francisco, CA, Amer. Meteor. Soc., 764-767.

— 1997: On the absence of population bias in the tornado climatology of southwestern Ontario. Wea. Forecasting, 12, 939946.
M. J. Leduc, and B. P. Murphy, 1996: The climatology of tornadoes in southern Ontario: Possible effects of lake breezes. Preprints, 18th Conf. on Severe Local Storms, San Francisco, CA, Amer. Meteor. Soc., 627-630.

_- and Coauthors, 1999: ELBOW: An experiment to study the Effects of Lake Breezes On Weather in southern Ontario. CMOS Bull. SCMO, 27, 35-41.

Leduc, M., B. Murphy, and P. Joe, 1993: The structure and evolution of the 28 August 1990 tornado-producing supercell in southwestern Ontario. Preprints, 17th Conf. on Severe Local Storms, St. Louis, MO, Amer. Meteor. Soc., 164-167.

Lyons, W. A., 1971: Low level divergence and subsidence over the Great Lakes in summer. Proc. 14th Conf. on Great Lakes Research, Toronto, ON, Canada, Association for Great Lakes Research, 467-487.

Markowski, P. M., E. N. Rasmussen, and J. M. Straka, 1998: The occurrence of tornadoes in supercells interacting with boundaries during VORTEX-95. Wea. Forecasting, 13, 852-859.

Murphy, B. P., 1991: Tornado and flash flood in southwestern Ontario on 31 May 1991. Ontario Region Tech. Note ORTN-91-3, 8 pp. [Available from Library, Meteorological Service of Canada, 4905 Dufferin St., Toronto, ON M3H 5T4, Canada.]

Newark, M. J., 1984: Canadian tornadoes, 1950-1979. Atmos.Ocean, 22, 343-353.

Pielke, R. A., 1974: A three-dimensional numerical model of the sea breezes over south Florida. Mon. Wea. Rev., 102, 115-138.

—_, 1984: Mesoscale Meteorological Modeling. Academic Press, $612 \mathrm{pp}$.

Purdom, J. F. W., 1976: Some uses of high-resolution GOES imagery in the mesoscale forecasting of convection and its behavior. Mon. Wea. Rev., 104, 1474-1483.

Qiu, X., 2002: High-resolution mesoscale meteorological modelling in southern Ontario. Ph.D. thesis, York University, 226 pp.

Savijarvi, H., and M. Alestalo, 1988: The sea breeze over a lake or gulf as the function of the prevailing flow. Beitr. Phys. Atmos., 61, 98-104.

Shenfeld, L., and F. D. Thompson, 1962: The thunderstorm of August 9, 1961 at Hamilton, Ontario, Canada. Meteorological Branch CIR 3683, TEC-417, Department of Transport, 24 pp. [Available from Library, Meteorological Service of Canada, 4905 Dufferin St., Toronto, ON M3H 5T4, Canada.]

Sills, D. M. L., 1998: Lake and land breezes in southwestern Ontario: Observations, analyses and numerical modelling. Ph.D. thesis, York University, $338 \mathrm{pp}$.

_ , and P. W. S. King, 1998: The 1997 ELBOW project: High resolution modeling of lake breezes in a pre-storm environment. Preprints, 19th Conf. on Severe Local Storms, Minneapolis, MN, Amer. Meteor. Soc., 23-26.

- and — 2000: Landspouts at lake breeze fronts in southern Ontario. Preprints, 20th Conf. on Severe Local Storms, Orlando, FL, Amer. Meteor. Soc., 243-246.

__ P. A. Taylor, and J. R. Salmon, 1994: Southern Ontario oxidant study-Meteorological measurements. Final Data Rep., York University, $87 \mathrm{pp}$.

— , P. Taylor, P. King, W. Hocking, and I. Nichols, 2002: ELBOW 2001-Studying the relationship between lake breezes and severe weather: Project overview and preliminary results. Preprints, 21th Conf. on Severe Local Storms, San Antonio, TX, Amer. Meteor. Soc., 611-614.

Simpson, J. E., 1994: Sea Breeze and Local Wind. Cambridge University Press, $234 \mathrm{pp}$.

Wakimoto, R. M., and J. W. Wilson, 1989: Non-supercell tornadoes. Mon. Wea. Rev., 117, 1113-1140.

Wexler, R., 1946: Theory and observations of land and sea breezes. Bull. Amer. Meteor. Soc., 27, 272-287.

Wilson, J. W., and W. E. Schreiber, 1986: Initiation of convective storms at radar-observed boundary-layer convergence lines. Mon. Wea. Rev., 114, 2516-2536. 